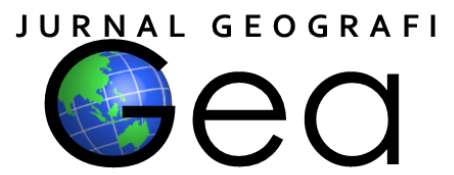

\title{
STUDY OF FLOOD-PRONE AREAS IN BEKASI REGENCY
}

\author{
Ina Helena Agustina \\ Urban and Regional Planning Study Program, Faculty of Engineering, \\ Universitas Islam Bandung \\ inahelena66@gmail.com
}

\begin{abstract}
Bekasi Regency is a potential area economically because there is the largest industrial area in Southeast Asia. However, Bekasi experiences the threat of flooding every year. The growth of the Bekasi Regency area has been affected by the growth of the Jakarta area, even becoming part of the JABODETABEK Metropolitan area (Jakarta-Bogor-DepokTangerang-Bekasi. This shows a potential location for economic growth in Bekasi Regency. Bekasi Regency is a West Java Province Region and is hydrologically included in the Regional Unit River (SWS) from the Citarum River Basin. The purpose of this study is to describe flood-prone areas in Bekasi Regency. The research method uses data collection methods by means of surveys and field observations. The data obtained are primary and secondary data, analyzed using ARCH GIS assistance to map flood-prone areas and their inundation and drainage channel conditions. The study findings will provide lessons on flood cases in Bekasi Regency. Flood cases that can provide knowledge related to cases of coastal areas and cases of areas that have high economic potential.
\end{abstract}

Keywords: Bekasi-Regency; DAS Citarum-Areas; Flood-prone-areas.

\section{INTRODUCTION}

Floods are a serious threat to countries in the world and are expected to increase due to climatic and non-climatic factors such as changes in land use and rivers (Vinke-de Kruijf, Kuks, \& Augustijn, 2015). Future climate change threatens the flow of the Kosal river (Chim, Tunnicliffe, Shamseldin, \& Bun, 2021). Climate change affects local ecological changes (Asante, Guodaar, \& Arimiyaw, 2021). Change climate threatens global sustainability, especially in rural communities in developing countries (Qazlbash, Zubair, Manzoor, Haq, \& Baloch, 2021). Climate change poses new threats to humans and the environment.

Flooding is the occurrence of inundation in the floodplain as a result of water and river runoff caused by the flow of water flowing in the river exceeding its flowing capacity. In addition to the occurrence of river runoff, flood inundation can also occur due to local rain with a fairly high rainfall where inundation occurs; as well as due to the occurrence of tides from the sea. These three events can occur simultaneously or separately. Floods are a natural part of the hydrologic cycle. However, they cause death, displacement of people, and environmental damage that can also seriously harm economic development (Matej Vojtek \& Jana Vojteková 2016).

The growth of the Bekasi Regency area was affected by the growth of the Jakarta area, even becoming part of the JABODETABEK Metropolitan area (Jakarta-Bogor-Depok-TangerangBekasi), as a result the growth of built-up land in this area has developed rapidly. 
Bekasi Regency is the largest industrial area in Southeast Asia. Therefore, housing and commercial development in the Bekasi Regency area has grown sporadically. The acceleration of development in Bekasi Regency must take into account the principles of sustainable development, unfortunately this region has flood-prone areas.

The purpose of this study is to describe flood-prone areas in Bekasi Regency. The study findings will provide lessons for flood cases in Bekasi Regency. Flood cases can be observed from several things, such as basic physical conditions, land development conditions and channel infrastructure. The flood phenomenon has an impact on environmental degradation and regional development in Bekasi Regency.

\section{RESEARCH METHOD}

\section{Context of Study}

Bekasi Regency is located in West Java Province, Republic of Indonesia. Geographical position of this Regency is $6^{\circ} 1^{\circ 1}-6^{\circ} 3^{\circ 1}$ South Latitude $106^{\circ} 48^{\prime} 78^{\prime \prime}$ $107^{\circ} 27^{\prime} 29^{\prime \prime}$ East Longitude, this position places Bekasi Regency in the west of West Java Province which extends from north to south. The boundaries of Bekasi Regency: to the north are the Java Sea, to the south are Bogor Regency, to the west are DKI Jakarta and Bekasi City and to the east are Karawang Regency. This district has an administrative area of 23 sub-districts with a total area of 127,388 hectares. The geographical location which is directly adjacent to DKI Jakarta and is the JABODABEK area is a consideration in determining the research location.

Data Collection Procedure

Data collection is done by means of surveys to agencies to obtain secondary data. The research data collected are tabulation maps data and reports from Bappeda (Regional Planning and Development Agency) Bekasi Regency. In addition, data on flood areas in Bekasi
Regency from BPBD (Regional Disaster Management Agency) Bekasi Regency.

In addition, field observations related to flood areas in Bekasi Regency were conducted and equipped with a GPS device. Field observations were carried out by identifying drainage channels in the flooded area and collecting information from the community. The GPS tool helps to pinpoint the location of the drainage canal.

Data Analysis

Data analysis was carried out using Arc GIS software and interpreting the results of the map overlay, with the following steps: (1) the analog maps obtained were topographic maps, land maps, and land use maps which were converted into digital maps by inserting them into the software. GIS, ArcGIS. (2) The maps are overlaid to determine the flood area in the built area (3) make a drainage map from field observations (4) interpret the flood area with drainage conditions in the field as well as the results of community information.

\section{RESULTS AND DISCUSSION Flood Area and Drainage System}

Geographically, Bekasi Regency is located in the north of West Java Province and is in the lowlands, $72 \%$ of the Bekasi Regency area is at an altitude of 0-25 meters above sea level. Most of Bekasi area is lowland with hilly in the southern part. The altitude of the location is between 0 115 meters and the slope is $0-250$ meters. Bekasi Regency is a downstream area of the Citarum River watershed with a length of 2,068 $\mathrm{km}^{2}$. The rivers in Bekasi Regency are Cikarang River, Ciherang River, Blencong River, Jambe River, Sadang River, Cikedokan River, Ulu River, Cilemahabang River, Cibeet River, Cipamingkis River, Siluman River, Srengseng River, Sepak River, Jaeran River, and Bekasi River. Topographically and the slope of the Bekasi Regency area is a downstream area that has a great chance of flooding due to river overflow when the 
rainy season arrives. Flash flooding, is the main problem cited by downstream communities in the sub-watershed, which impact on agricultural land and livelihoods (Borgohain, 2019).

In fact, Bekasi Regency has Flood Prone Areas spread over 35 villages and 15 sub-districts. Flood-prone areas are relatively dominant when compared to areas that are not affected by flooding. The number of sub-districts alone includes 15 of the 23 sub-districts. The flooded area has an area of 30,700.27 Ha while the total area itself is 127,388 Ha. The flood inundation area is 6,239.30 Ha. This means that the Bekasi Regency area is a relatively wide flood threat. In addition, the drainage system in several areas has been damaged, this damage to the drainage canal will expand the area of inundation (see Figure 1). The drainage channel identification was obtained using a GPS device and field photo recordings (see Figure 2).

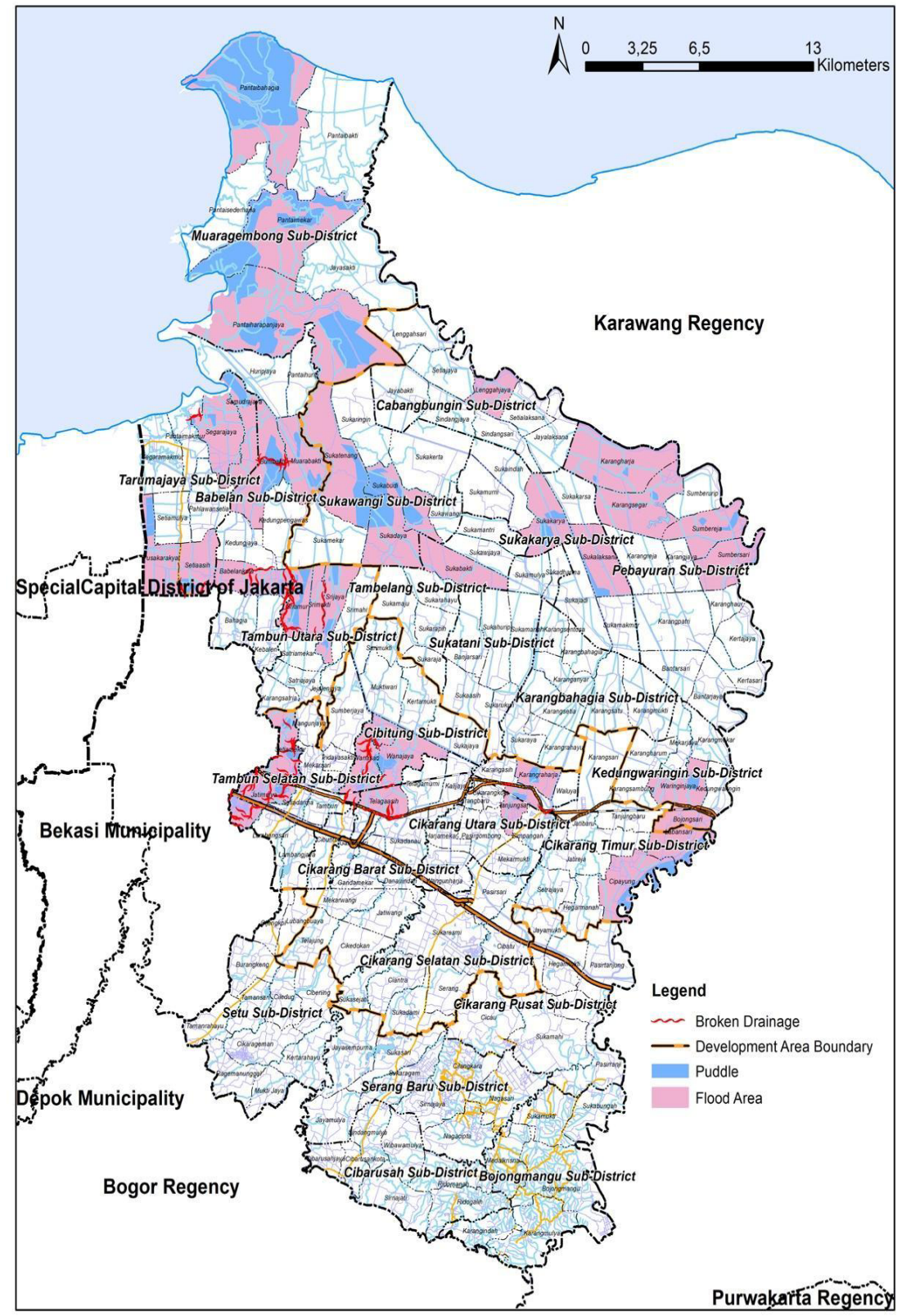

Figure 1. Distribution of damaged drainage channels 


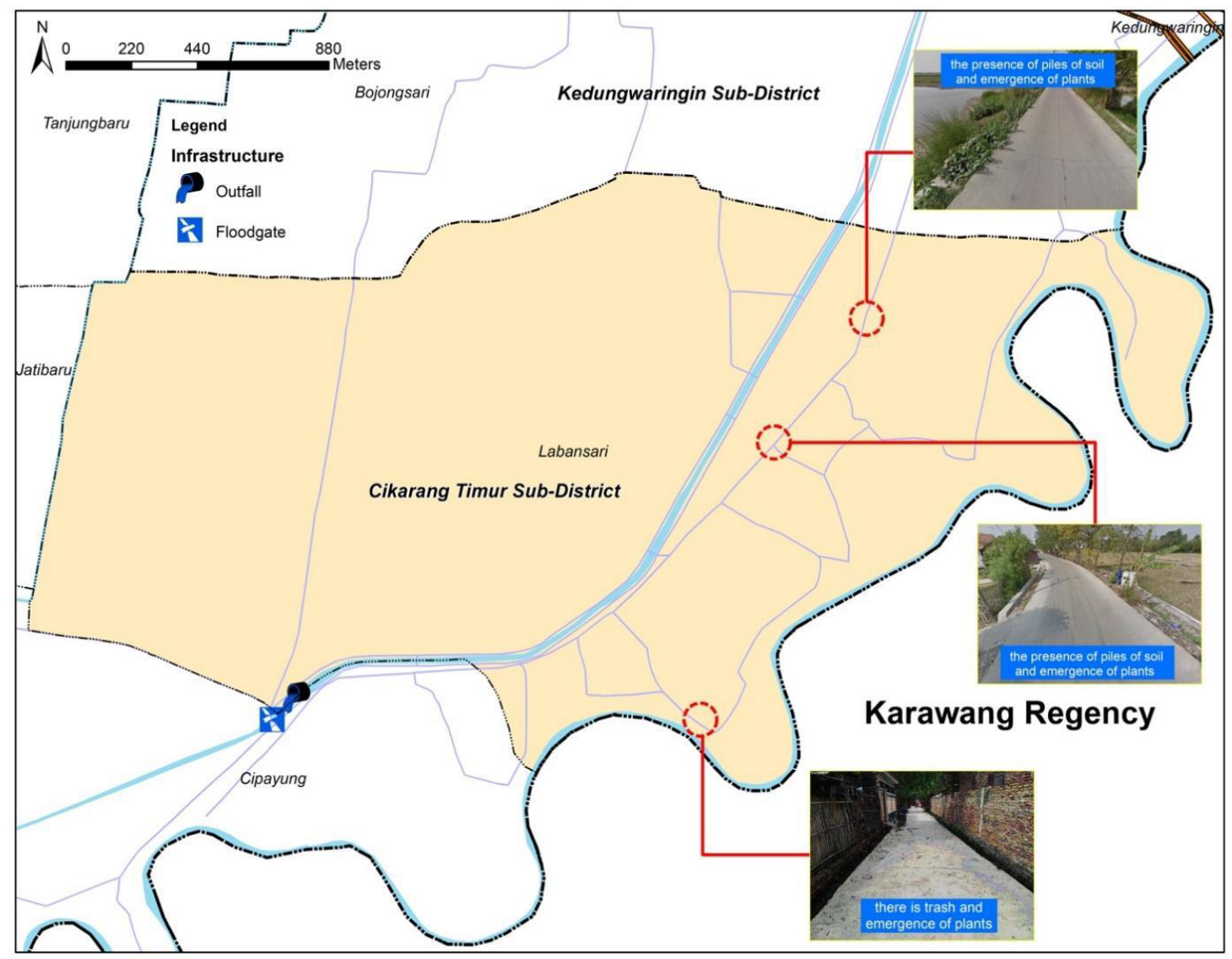

Figure 2. Position of Drainage Channels using a GPS device and recording photos of drainage channels in Laban Sari Village, East Cikarang District

The global warming will result in melting of Alpine ice and thermal expansion of seawater, which in turn will result in sea level rise. Climate change is also expected to result in an increase in the frequency and intensity of extreme events causing coastal areas to experience more severe storm surges and floods (Munji et al., 2013). The flooding that occurred in Bekasi Regency was not only due to its geographical location in the downstream and lowlands or coastal zones, the aspect of drainage infrastructure was also a contributing factor to flooding. Thus, flooding in Bekasi Regency cannot be avoided because nature is also the cause but also has problems with its infrastructure.

\section{Flood and Environmental Damage}

Floods that occur in the areas of Bekasi Regency affect the environment and regional development. It can be noted that in the northern part of Bekasi Regency there is Muara Gembong District which has the largest flood inundation area compared to other Districts, namely 3,832.27 Ha (see Figure 3). This area is a coastal area where the people live from agriculture and fish catches in the sea. Seasonal flooding can adversely affect human livelihoods, affect the ecological balance and cause environmental degradation (Seid Mohamad Mousavi, Shahram roostaei \& Hashem Rostamzadeh 2019). Possible outcomes include inland or seaward migration of mangroves, extinction of migratory bird species, endangerment of other plant and animal species, disruption of human settlements and ecosystems, coastal pollution, and saltwater intrusion into groundwater and estuaries. Floods bring great hardship to most rural and livelihood-based communities, who are among the most vulnerable to the impacts of climate variability and change (Munji et al., 2013). In addition, human interventions (e.g. flood control measures, land-use change and 
urbanization) are considered to have a significant impact on the frequency and magnitude of flooding (Alessio Ciullo, Alberto Viglione, Attilio Castellarin, Massimiliano Crisci \& Giuliano Di Baldassarre (2016).

Around $15.5 \%$ of Bekasi Regency area has groundwater intruded by seawater, especially in Muara Gembong and Tarumajaya Districts, $20.1 \%$ has deep groundwater and $64.4 \%$ has shallow groundwater. Groundwater conditions in the Bekasi Regency area are mostly shallow groundwater at a depth of 5-25 meters from the ground surface, while deep groundwater is generally obtained at a depth of 90-200 meters. Groundwater conditions in 5 sub-districts, namely Cikarang Central, North Cikarang, South Cikarang, West Cikarang, and East Cikarang have wells generally of 5 liters/sec. The depth of shallow aquifers can reach more than $25 \mathrm{~m}$. Depths vary between $5-8 \mathrm{~m}$ in mountainous areas and 2-4 $\mathrm{m}$ in local plains below ground level. The deep aquifer layer is at a depth of 40 - $140 \mathrm{~m}$ below the local land surface. Setu, Serang Baru, South Cikarang, Karang Bahagia, and Pebayuran sub-districts have moderate groundwater potential. Cibarusah and Bojongmangu subdistricts generally have small, local and scarce groundwater potential. The environmental conditions of Bekasi Regency are a development challenge.

Bekasi Regency, which is located in the lowlands and downstream, is a strategic area with the largest industrial area in Southeast Asia. Even from the existence of this industrial area, various large-scale residential buildings have grown rapidly, such as Deltamas and Meikarta. Large-scale settlement developments form new urban areas. The coastal zone has experienced rapid urban growth over the last 50 years and this is expected to continue. The most important reasons for rapid land use change are related to real estate pressures and the development of new urban infrastructure. Coastal systems support various social, economic and natural services and are directly affected by various human activities (Magarotto, Faria-De-Deus, Costa, \& Masanet, 2017). Drought, flooding, and water quality challenges pose significant threats, while at the same time, rapid urban expansion, competing water demands, river modification, and the expansion of global markets for water-intensive agricultural products are driving water insecurity (Scott et al., 2021)

Flash floods develop rapidly over time, which poses special challenges (Ritter, Berenguer, Corral, Park, \& Sempere-Torres, 2020). Climate change could lead to more frequent and severe flooding that would increase public health problems, including an increased risk of infectious diarrhea in vulnerable populations. Diarrhea is a flood-sensitive health outcome, and remains a major public health problem (Zhang et al., 2019). Floods can be caused by climate change factors and can also result in financial losses (Khandekar, Gorti, Bhadwal, \& Rijhwani, 2019)

Structural flood risk management towards integrated flood risk management, confirms that the governance structure supports the development and implementation of integrated flood risk management policies when taking into account all relevant levels, actors, perceptions, strategies and resources (high level) and has relationships between the various dimensions (Munji et al., 2013). 'Good' regional planning and management is considered a decision that is able to identify the real balance of environmental benefits (Cobbinah, Amenuvor, Black, \& Peprah, 2017). Disaster resilience has recognized the role of the natural environment in strengthening community resilience; however, pragmatic environmental indicators are still lacking (Abenayake, Mikami, Matsuda, \& Jayasinghe, 2018). The socio- 
ecological systems approach is very useful in dealing with human and ecological processes related to water resources and water security in particular. It also explores how communities practice knowledge innovation by making generalized and centralized flood forecast information applicable locally (Acharya \& Prakash, 2019). Knowledge developed through living in floodplains and surviving floods is proving to be more reliable for local communities (Acharya \& Prakash, 2019).

Floods can be caused by climate change factors and can also result in financial losses (Khandekar et al., 2019). The importance of environmental sustainability issues in anticipating flooding (Bojórquez-Tapia, Eakin, Hernández-Aguilar, \& Shelton, 2021). Achieving water security for humans and ecosystems is a global challenge. There needs to be a balance between environmental, economic, and social sustainability goals as an integrated process. Likewise, Bekasi Regency, whose territory has been partially transformed into urban areas and some is still rural. Balance has a greater chance of making an area greener, fairer and more profitable for all stakeholders (Bibri, Krogstie, \& Kärrholm, 2020). Complex thinking and socio-formation to promote sustainable social development, as well as to build a transdisciplinary process program focusing on collaborative processes aimed at bringing about the urgent transformations needed in social organization, education, production and consumption processes, urbanization and the protection of biodiversity (LunaNemecio, Tobón, \& Juárez-Hernández, 2020).

\section{CONCLUSIONS}

The Bekasi Regency area has a wider lowland landscape. In addition, it has a coastal zone and a downstream area of the Citarum watershed. Flood-prone areas spread over 35 villages and 15 subdistricts. Flood-prone areas have an area of 30,700.27 hectares while the total area itself is 127,388 hectares. The flood inundation area is 6,239.30 Ha. Floods that occur in this area are indicated due to natural factors and infrastructure factors that are not optimally integrated. Floods have consequences for environmental damage and financial losses, for that development in this area must return to sharpening the carrying capacity of the environment and involving development actors continuously. Indicators of sustainable development that consider physical, social and economic aspects.

\section{Acknowledgement}

Thank you to the Urban and Regional Planning Study Program UNISBA Faculty of Engineering for supporting this research. Thanks also to the Regional Development Planning Agency (BAPPEDA) of Bekasi district for assisting this research.

\section{RECOMMENDATIONS}

Recommendations are things that need to be followed up by readers as future researchers, certain professions or certain office holders. Recommendations must be written using solid paragraphs.

\section{REFERENCES}

Abenayake, C. C., Mikami, Y., Matsuda, Y., \& Jayasinghe, A. (2018). Ecosystem services-based composite indicator for assessing community resilience to floods. Environmental Development, 27, 34-46. https://doi.org/10.1016/j.envdev.2 018.08.002

Acharya, A., \& Prakash, A. (2019). When the river talks to its people: Local knowledge-based flood forecasting in Gandak River basin, India. Environmental Development, 31, 55-67. https://doi.org/10.1016/j.envdev.2 
018.12 .003

Alessio Ciullo, Alberto Viglione, Attilio Castellarin, Massimiliano Crisci \& Giuliano Di Baldassarre (2016): Socio-hydrological modelling of flood-risk dynamics: comparing the resilience of green and technological systems, Hydrological Sciences Journal, DOI: 10.1080/02626667.2016.1273527

Asante, F., Guodaar, L., \& Arimiyaw, S. (2021). Climate change and variability awareness and livelihood adaptive strategies among smallholder farmers in semi-arid northern Ghana. Environmental Development, 39(March), 100629. https:// doi.org/10.1016/j.envdev.2 021.100629

Bibri, S. E., Krogstie, J., \& Kärrholm, M. (2020). Compact city planning and development: Emerging practices and strategies for achieving the goals of sustainability. Developments in the Built Environment, 4, 100021. https://doi.org/10.1016/j.dibe.2020. 100021

Bojórquez-Tapia, L. A., Eakin, H., Hernández-Aguilar, B., \& Shelton, R. (2021). Addressing complex, political and intransient sustainability challenges of transdisciplinarity: The case of the MEGADAPT project in Mexico City. Environmental Development, 38, 100604. https://doi.org/10.1016/j.envdev.2 020.100604

Borgohain, P. L. (2019). Downstream impacts of the Ranganadi hydel project in Brahmaputra Basin, India: Implications for design of future projects. Environmental Development, 30(July 2018), 114-128. https:// doi.org/10.1016/j.envdev.2 019.04.005

Chim, K., Tunnicliffe, J., Shamseldin, A. Y., \& Bun, H. (2021). Assessment of land use and climate change effects on hydrology in the upper Siem Reap River and Angkor Temple Complex,
Cambodia.

Environmental

Development, 39(February), 100615. https://doi.org/10.1016/j.envdev.2 021.100615

Cobbinah, P. B., Amenuvor, D., Black, R., \& Peprah, C. (2017). Ecotourism in the Kakum Conservation Area , Ghana : Local politics, practice and outcome. Journal of Outdoor Recreation and Tourism, 20(June), 34-44. https://doi.org/10.1016/j.jort.2017. 09.003

Khandekar, N., Gorti, G., Bhadwal, S., \& Rijhwani, V. (2019). Perceptions of climate shocks and gender vulnerabilities in the Upper Ganga Basin. Environmental Development, 31(February), 97-109. https://doi.org/10.1016/j.envdev.2 019.02.001

Luna-Nemecio, J., Tobón, S., \& JuárezHernández, L. G. (2020). Sustainability-based on socioformation and complex thought or sustainable social development. Resources, Environment and Sustainability, 2(July), 100007. https://doi.org/10.1016/j.resenv.20 20.100007

Matej Vojtek \& Jana Vojteková (2016):Flood hazard and flood risk assessment at the local spatial scale: a case study, Geomatics, Natural Hazards and Risk, DOI: 10.1080/19475705.2016.1166874

Magarotto, M., Faria-De-Deus, R., Costa, M. F., \& Masanet, É. (2017). Green areas in coastal cities - Conflict of interests or stakeholders' perspectives? International Journal of Sustainable Development and Planning, 12(8), 1260-1271. https:/ / doi.org/10.2495/SDP-V12N8-1260-1271

Munji, C. A., Bele, M. Y., Nkwatoh, A. F., Idinoba, M. E., Somorin, O. A., \& Sonwa, D. J. (2013). Vulnerability to coastal flooding and response strategies: The case of settlements in 
Cameroon mangrove forests. Environmental Development, 5(1), 5472. https:/ / doi.org/10.1016/j.envdev.2 012.10 .002

Qazlbash, S. K., Zubair, M., Manzoor, S. A., Haq, A. ul, \& Baloch, M. S. (2021). Socioeconomic determinants of climate change adaptations in the flood-prone rural community of Indus Basin, Pakistan. Environmental Development, 37(December), 100603. https://doi.org/10.1016/j.envdev.2 020.100603

Ritter, J., Berenguer, M., Corral, C., Park, S., \& Sempere-Torres, D. (2020). ReAFFIRM: Real-time Assessment of Flash Flood Impacts - a Regional high-resolution Method. Environment International, 136(November 2019), 105375. https:// doi.org/10.1016/j.envint.20 19.105375

Scott, C. A., Zilio, M. I., Harmon, T., Zuniga-Teran, A., Díaz-Caravantes, R., Hoyos, N., ... Pineda, N. (2021). Do ecosystem insecurity and social vulnerability lead to failure of water security? Environmental Development, 38, 100606. https:// doi.org/10.1016/j.envdev.2 020.100606

Seid Mohamad Mousavi, Shahram roostaei \& Hashem Rostamzadeh (2019) Estimation of flood land use/land cover mapping by regional modelling of flood hazard at subbasin level case study: Marand basin, Geomatics, Natural Hazards and Risk, 10:1, 1155-1175, DOI: 10.1080/19475705.2018.1549112

Vinke-de Kruijf, J., Kuks, S. M. M., \& Augustijn, D. C. M. (2015). Governance in support of integrated flood risk management? The case of Romania. Environmental Development, 16 , 104-118. https:/ / doi.org/10.1016/j.envdev.2 015.04 .003
Zhang, N., Song, D., Zhang, J., Liao, W., Miao, K., Zhong, S., ... Huang, C. (2019). The impact of the 2016 flood event in Anhui Province, China on infectious diarrhea disease: An interrupted time-series study. Environment International, 127(January), 801-809. https://doi.org/10.1016/j.envint.20 19.03.063 